UDC 658

DOI: $10.24045 /$ et.2017.1.4

\title{
IMPROVING PROCUREMENT MANAGEMENT SYSTEM AT THE COMPANY DURING BUSINESS NEGOTIATIONS IN ENGLISH
}

\author{
V. A. Tunnikova \\ K. R. Avanesyan
}

\author{
Candidate of Economic Sciences \\ undergraduate student \\ Rostov State Economic University "RINH" \\ Rostov-on-Don, Russia
}

\begin{abstract}
The main content of this study is to uncover all the management methods in order to monitor successfully the activity of the company in the negotiations, particularly when that activity is carried out in English. The main emphasis is given to procurement management, as this is an important part of any business, especially businesses and for fast food company "Vkusnolyubov". The main purpose of this study is to investigate the issues of developing a package to optimize the procurement of logistics, both theoretical aspects and practical for a particular company, with considering that the negotiations are in a foreign language.
\end{abstract}

Keywords: package, negotiations, purchasing, logistics, partners, kosher food, innovation, procurement, production, marketing.

Procurement Logistics - it's materials management system in the process of providing enterprise with material resources. Any business, both production and trade, is composed of services involved in the purchase, delivery and temporary storage of raw materials, intermediate goods and consumer goods. Therefore, coverage of procurement logistics issues is relevant.

Based on the targets in the given work the following tasks were made:

- To consider the essence of procurement logistics in general.

- Explore Organization of procurement logistics an example of the "Vkusnolyubov" enterprise.

- To find out main problems when dealing with partners and the role of the English language.

- Ways to solve these problems [1].
Realization of this goal is based on the principles of openness, transparency of information about the contract system in the procurement; promoting competition; customers of professionalism; stimulate innovation; the unity of the contract system in the procurement; responsibility for ensuring the effectiveness of the needs; effectiveness of the implementation of procurement rules and clearly comprehensible communication with foreign partners.

In modern conditions, when the competition is quite high and it is increasing every year, heads of commercial enterprises pursuing goals such as profit maximization, the consolidation of the situation in the market, creating a positive image and strengthening of the network brand, the timely introduction of innovation and growth in network 
capacity, motivation and encouraging staff to make effective use of resources, the attainment of which is possible only through the introduction of automated logistics systems [2].
Ensuring an appropriate degree of synergy between the internal management of material flows, it is the task of organizing the logistics of the enterprise in general.

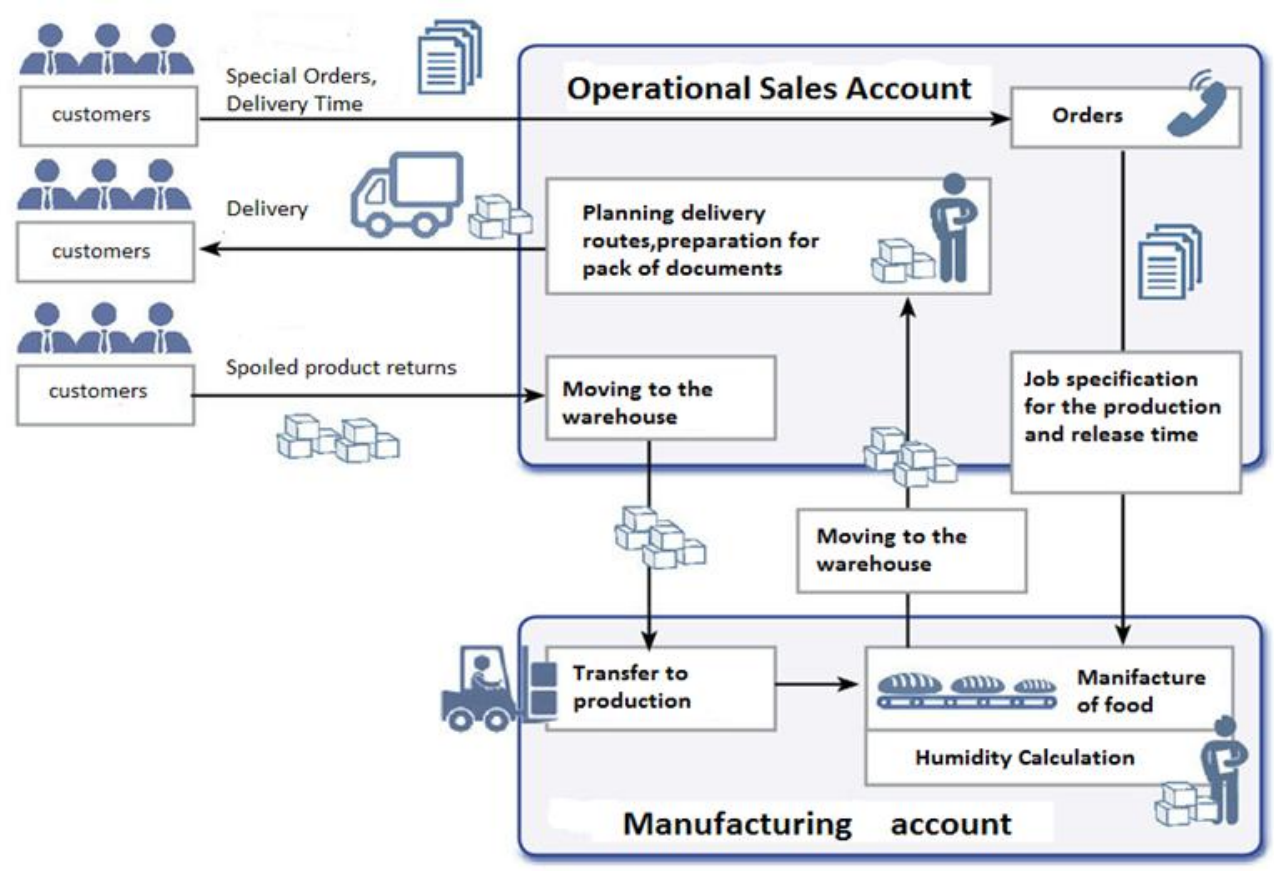

Plc 1 Logistical chain "purchases - processing - realization" on "Vkusnolyubov" enterprise (composed by author).

Logistical chain "purchases - processing - realization" should be based on the concept of marketing that means that the volume should be based on the strategy of enterprises orders buyers. First, marketing strategy should be developed, then, on the basis of it, the development strategy of commercial enterprise and after enterprise strategy of supply. That is, procurement process at this stage.

Scientific marketing tools aimed at a comprehensive study of a market do not contain methods to solve the technological problems of consistency with the suppliers based on the requirements identified in the study of market. Also, it does not offer a system and methods for organizing all participants in the process of promotion materials from the primary source of raw materials to the end consumer.

In this context, logistics is developing a marketing approach to entrepreneurship, accumulating methods to implement the concept of marketing, significantly expands and complements the concept [3].

"VKUSNOLYUBOV" Company, Russia's largest food chain, mostly pancake products. The total cost for implementing of innovation according to the estimates for the 2016-2017 year is 2147 rubles, while the current 
expenses of the enterprise constitute 957 thousand rubles, and the direct costs 1190 thousand rubles. The direct costs include: drawing up technical specifications for the implementation of special information systems that improve work of enterprise, "Monolith" and "IIko", projection of IS modules, testing and implementation of systems, special training.

The current also includes: the cost of supporting IS "Monolith" and "IIko", specialist's salaries, the cost of fuel and maintenance of the car, the driver's salary.

It is planned to increase the budget of the enterprise on the basis of cooperation with foreign partners, but here you must be able to communicate in English in professional level. Now company already has an active teaching process of foreign language to personnel, since it already had a very significant experience that taught it to many things.

The fact that "Vkusnolyubov" was the official food operator in the Olympic Games in Sochi c1ty in 2014 and since then it got partners from Israel, interested to cooperate with it in future. Conditions were as: "Vkusnolyu- bov" provides players and spectators of sport competition with food, most game guests are Jews, and they in return provide a good advertising for a company and the opportunity to be the official sponsor of games during the 5 years. These partners have offered to the company to produce some new products, such as hot dogs.

There has been some issue, when it was associated with the supply of sausages, as the shipment had to come just from kosher beef. It is wellknown, that Jews eat only kosher meat. And for the guests and the audience they are also perceived only kosher meat, but as business partners they did not specifically articulate it, as it was stated in the contract already.

However, "Vkusnolyubov" neglected that fact in the contract, which obviously points to the negligence of employees or simply the inability to understand the text in a foreign language. Later it came to agreement with the partners, but of course it could result in a rupture of the contract and the loss of large amount of money and clients base. 
Business English and its role in the enterprise

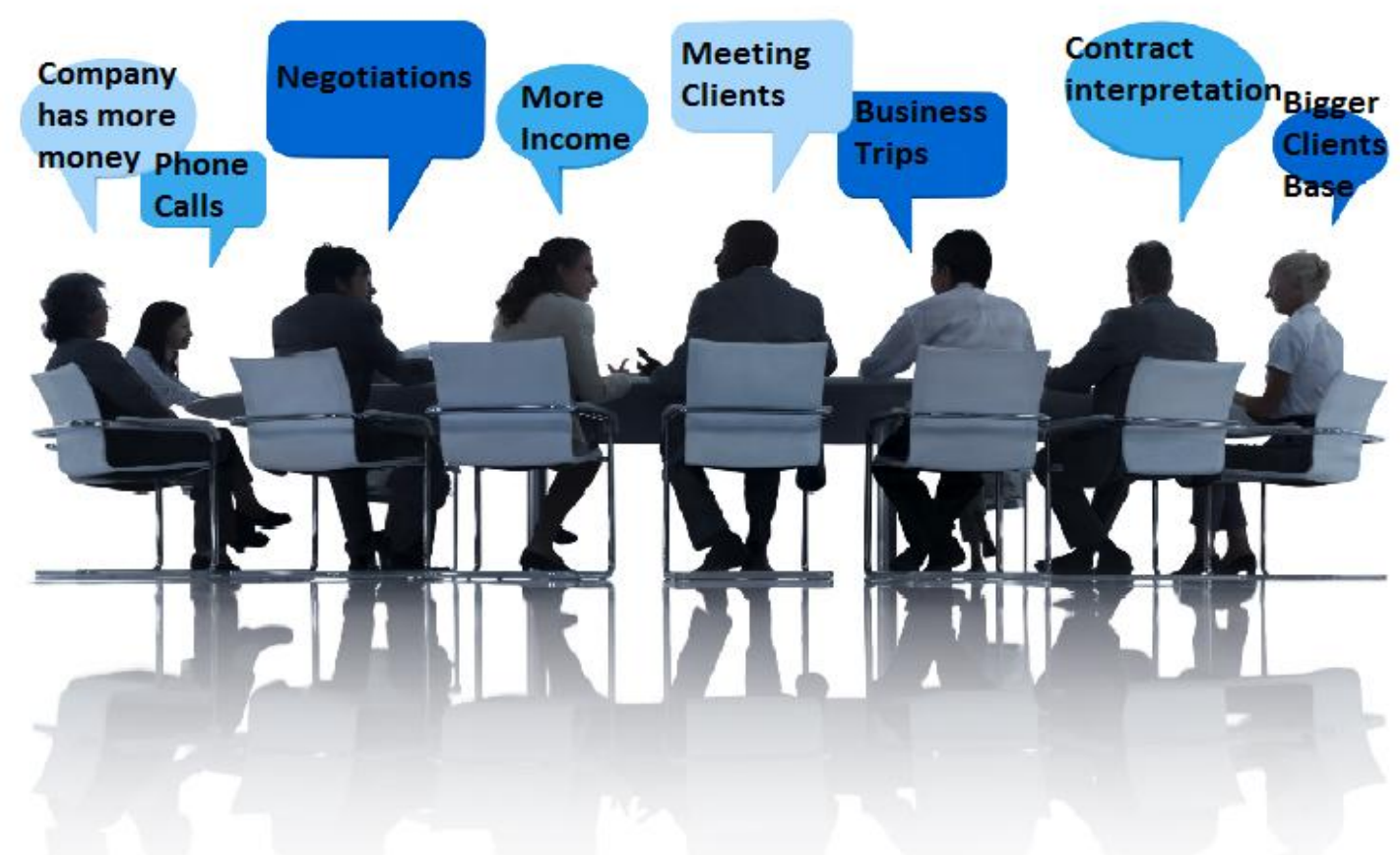

Pic 2. The Business English Role in Providing Enterprise Activity (composed by author)

Typical problems of procurement logistics:

1. Lack of necessary goods at the right time (or deficit)

2. The presence of excess inventory of goods in stock of finished goods (materials)

3. The supply disruption due to transportation companies and domestic turmoil.

4. A large number of misunderstandings that may remain even after a detailed study of the supply contract. This is due to lack of organization of the enterprise as a whole, since the workers are not trained to understand and strictly follow the rules of regulation, especially in a foreign language.

5. No claims to suppliers, with the presentation of all the costs and expenses of the company (usually the order is just reducing or goods are exchanging, which proved to be spoiled)
These five typical problems found on $75 \%$ of sales and $64 \%$ of industrial Russian companies. This emphasizes again the need for improvement and implementation of these recommendations.

The main ways of increasing efficiency in the procurement logistics "Vkusnolyubov" company are:

1. Allocate funds for additional staff training, add some more amount to salaries, that way it could be a stimulus to learn English.

2. Develop or acquire automated forecasting and supply planning product.

3. Development of recoil schemes in procurement: for example, to split the purchase cycle (planning, implementation, monitoring and analysis) for various departments.

4. To get hire a skilled foreign worker, if that's possible. Give him the opportunity to do an internship on the 
domestic enterprise at the additional cost, So, he is like teaching chip, who would show his way of acting in negotiating and would teach our compatriots to many tricks [4].

Activity of any enterprise, in both the production and trade cannot do well without procurement services. As an element of the macro logistical system supply service establishes economic connections with suppliers. Supply Service, as part of the enterprise that organized by it, fits in micro logistical system that ensures the passage of material flow in the chain of "supply - production - sales ".

The main task for commercial enterprise is the purchase and sale of goods in order to meet the needs of the population, with a minimum level of distribution costs and to obtain a sufficiently high level of profit. Significant role in the effective operation of the company plays an effective construction of its logistics system.

An important role is also played by the ability to understand partners. After all, even the ability to talk is not always enough. But what is more important is the ability to pay attention to detail.

So we should understand that any business, not just "Vkusnolyubov" is simply obliged to train their staff properly communicate in a business speech and not to neglect the small details. Besides of the language, other factors played a significant role in the im- plementation of the procurement activities of the enterprise, but we have already been discussed them extensively.

\section{Bibliography}

1. Coursework entitled as "Procurement management in the trading company (for example, Ltd."

Orio») [http://studentbank.ru/]

2. Альбеков А. У. Логистика в управлении коммерческим товарооборотом вторичных материальных ресурсов. СПб : Изд-во Нева, 2014.

3. Миротин Л. Б. Логистика интегрированных цепочек поставок. - М. : Брандес, 2005.

4. Coursework on discipline: "Logistics" entitled as "Organization of service management in the procurement logistics" Korotaeva Valeria

\section{Bibliography}

1. Coursework entitled as "Procurement management in the trading company (for example, Ltd." Orio ») [http://studentbank.ru/]

2. Al'bekov A. U. Logistika v upravlenii kommercheskim tovarooborotom vtorichnyh material'nyh resursov. $-\mathrm{SPb}$ : Izd-vo Neva, 2014.

3. Mirotin L. B. Logistika integrirovannyh cepochek postavok. - M. : Brandes, 2005.

4. Coursework on discipline: "Logistics" entitled as "Organization of service management in the procurement logistics" Korotaeva Valeria

(C) Tunnikova V.A., Avanesyan K. R., 2017. 